\title{
Тенденции, спрос и развитие оптико-волоконной промышленности
}

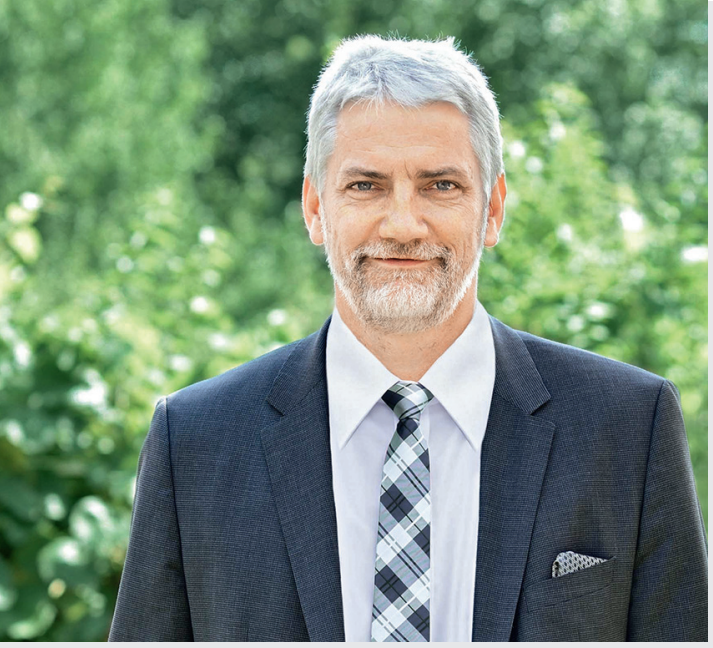

Тимо Ид, технический директор и управляющий директор бизнес-единицы Nextrom группы компаний Knill

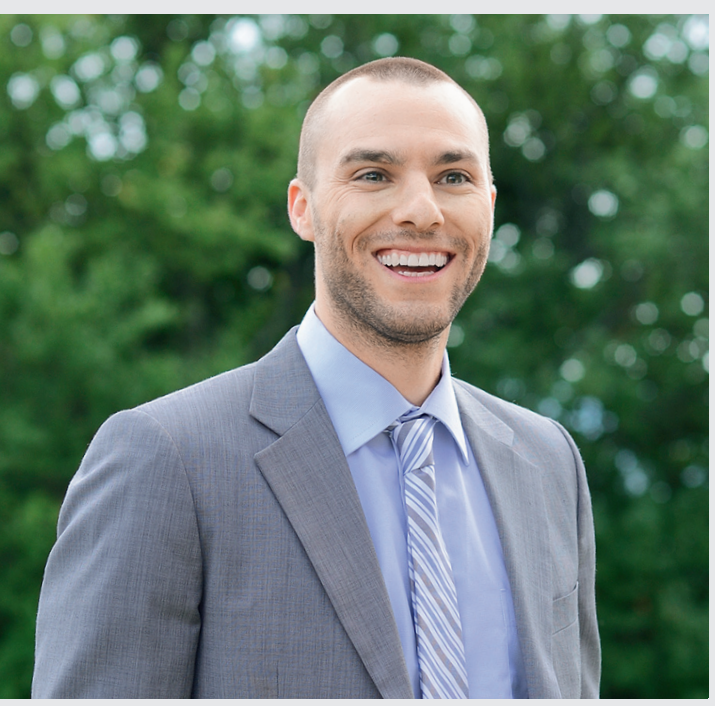

Кевин Боли, продукт-менеджер оборудования для производства специализированного оптического волокна
Сегодня в оптоволоконной промышленности мы наблюдаем высокую конкуренцию, особенно в области производства стандартного телекоммуникационного волокна. Однако бурное развитие высокотехнологичных отраслей промышленности требует все большего использования волоконных лазеров и самых разнообразных волоконнооптических датчиков, и это стимулирует конструкторскую мысль. Для создания лазеров, кабелей доставки лазерного излучения в рабочую зону необходимы волокна большого диаметра, а волокна малого диаметра требуются для изготовления FBG-датчиков, гироскопов, медицинских эндоскопических инструментов.

Чтобы прояснить ситуацию в современной оптоволоконной промышленности, мы обратились с вопросами к специалистам компании Rosendahl Nextrom. Профессионалам хорошо знакомы технология и оборудование компании Nextrom для производства оптического волокна. Дать интервью согласились технический директор и управляющий директор бизнес-единицы Nextrom группы компаний Knill Тимо Ид и продукт-менеджер оборудования для производства специализированного оптического волокна Кевин Болл. Nextrom является мировым лидером в области решений для производства волокон. Тимо работает в компании уже около 30 лет и имеет огромный экспертный опыт в данной промышленности. Кевин Болл окончил Мичиганский технологический университет в 2003 году по специальности машиностроение, работать в Nextrom пришел в 2006 году в качестве инженера-механика, специализирующегося на конструкции башни ватяжки специализированного волокна, в 2011 стал продукт-менеджером башен вытяжки специализированного волокна, в 2015 - менеджером по продажам практически всего оборудования для производства специализированного волокна. В настоящее время продукт-менеджер полной линейки оборудования и эксперт в области технологии и производства специализированного волокна.
Уважаемые г-н Тимо Ид и г-н Кевин Болл! В каком состоянии, на ваш взгляд, находится производство оптического волокна. Растет ли оптико-волоконная промышленность? Можете ли вы предсказать развитие отрасли в ближайшие 1,5-2 года?
Г-н Тимо Ид: В настоящее время на рынке телекоммуникационного оптического волокна отмечается некоторая неопределенность. После нескольких лет быстрого роста и расширения рынок выровнялся. Будущее будет в значительной степени зависеть от развития 


\title{
Trends, Demand and Development in Optical Fiber Industry
}

\begin{abstract}
Today, in the fiber optic industry, we see high competition, especially in the production of standard telecommunications fiber. However, fast development of high-tech industries requires increasing usage of fiber lasers and a wide variety of fiber optic sensors, and this stimulates research and development constantly. Large-diameter fibers are needed to produce laser cables, for example, delivering laser light to the working area in many factories in different industries at the same time small-diameter fibers are required to make FBG sensors, gyroscopes, medical endoscopic instruments.

To clarify the situation in fiber industry, we addressed our questions to the specialists of Rosendahl Nextrom. Experts are familiar with Nextrom's technology and equipment for the production of optical fiber. We interviewed Managing and Technical Director of the Business Unit Nextrom, Knill Group of Companies Timo Id and Product Manager of equipment for the production of specialty optical fiber Kevin Boll. Nextrom is a world leader in fiber solutions. Timo has been working in the company for about 30 years and has a great experience in optical fiber industry. Kevin Boll has graduated from Michigan Technological University in 2003 with a degree in Mechanical Engineering. Started at Nextrom in 2006 as a mechanical engineer specializing on draw tower design and became product manager for the specialty fiber draw tower in 2011 and sales manager for all specialty fiber draw products in 2015. Currently product manager for all specialty fiber products.
\end{abstract}

Mr. Id and Mr. Boll based on your opinion what is the situation with optical fiber production on the market? Is the optical fiber industry growing? Can you predict the development of the industry within the next $1.5-2$ years?

Mr.Id: There is some uncertainty in the telecom optical fiber market at the moment. After years of rapid growth and expansion, growth has leveled off. There is some uncertainty for future years which will depend greatly on fiber deployment for $5 \mathrm{C}$ networks, for DC, FTTH expansion and long distance network development.

Fiber supply capacity now exceeds global demand, but preform capacity not all available for every draw plant. Mismatch of demand between local/vs imports, fiber supplier and cablers relation, fiber draw and preform technology, still requires capacity to be well over sum of all demands.

Mr. Boll: The specialty optical fiber market continues strong growth led by advances in fiber lasers and optical fiber sensors

Do you expect the new technologies to enter the market?
Mr.Id: From the telecom side, there is a constant push to reduce attenuation and increase the data rate through fibers. Future developments will likely require new fiber types and technologies, but what will dominate the market in future years is still unclear

Mr. Boll: In specialty optics, there are continualy new technologies and applications entering the market such as new laser technologies and new types of sensors.

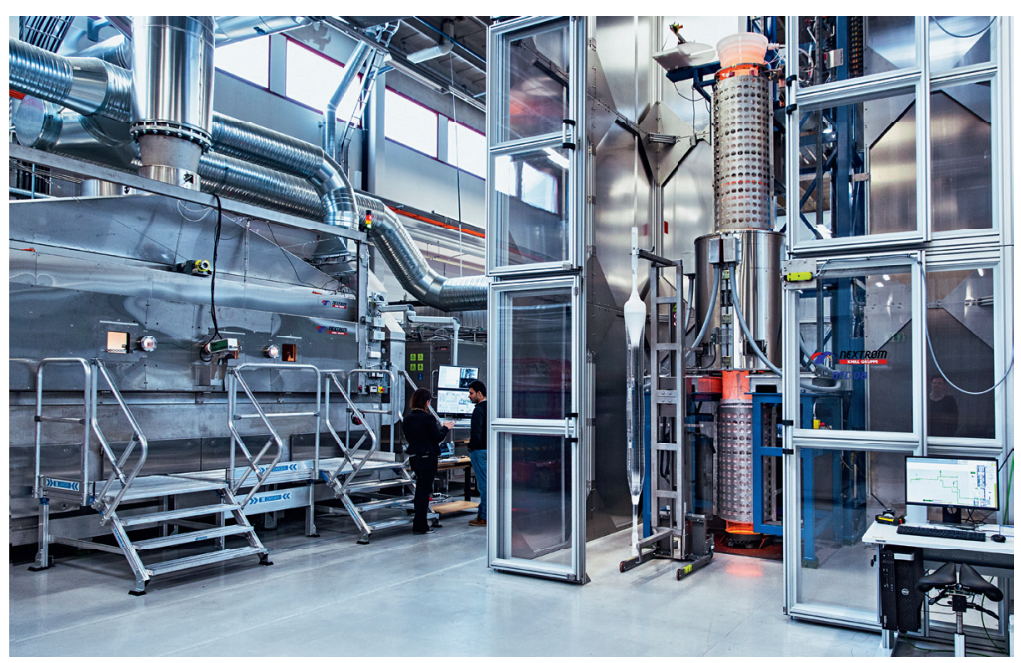


сетей 5G, роста в сфере FTTH, развития сетей ЦОД, а также сетей дальней связи.

Предложение волокна сейчас, возможно, и превышает мировой спрос, но в то же время предложение преформ ограничено и недостаточно для всех производителей волокна (технологическое несоответствие). Несоответствие спроса на местное и импортное волокно, отношения поставщиков волокна и производителей кабеля, технологии вытяжки волокна и технологии производства преформ, по некоторым направлениям необходимо увеличение мощностей для того, чтобы удовлетворить спрос.

\section{Предложение волокна сейчас, возможно, и превышает мировой спрос, но в тоже время предложение преформ ограничено и недостаточно...}

Г-н Кевин Болл: Рынок специализированного оптического волокна продолжает сильный рост, обусловленный достижениями в области волоконных лазеров и оптических волоконных сенсоров.

Ожидаете ли вы, что новые технологии будут представлены на рынке?

т.и.: Со стороны телекоммуникационного оптического волокна на рынке отмечается постоянный запрос на уменьшение затухания и увеличение скорости передачи данных с помощью волокон. Будущие разработки скорее всего потребуют новых типов волокон и технологий, но то, что будет доминировать на рынке в последующие годы, до сих пор неясно.

К.Б.: Со стороны специализированного оптического волокна рынок постоянно внедряет новые технологии и направления, например, такие, как новые лазерные технологии и новые виды сенсоров.

Производит ли компания такие продукты, как структурированные волокна и волокна с заполненной газом сердцевиной?

Т.И.: Rosendahl Nextrom является производителем оборудования, которое позволяет нашим клиентам делать оптические волокна и кабель. У нашей компании много клиентов, которые в настоящее время производят данные виды волокон .

Беспроводная связь, является ли эта технология угрозой для оптиковолоконной промышленности?

Т.и.: На самом деле, беспроводная связь ограничена расстоянием, и в настоящее время беспроводные передатчики и приемники подключены к оптиковолоконным сетям. Из-за помех в окружающей среде, физических и ЭМ-помех беспроводная связь не может реально удовлетворить требованиям по пропускной способности на дальние расстояния, в то время как оптические волокна могут.

Сколько времени занимает разработка нового продукта?

т.И.: Это во многом зависит от продукта и сложности. Некоторые разработки могут быть очень наукоемкими и сложными и занять 5-10 лет от начала разработки и до выхода на коммерческий рынок.

Каков жизненный цикл продукта например, для башни вытяжки Draw Tower?

Т.и.: Многие из башен вытяжки Nextrom, установленные 20 лет назад, все еще используются в производстве. Отдел сервиса и послепродажного обслуживания Nextrom постоянно поддерживает своих клиентов. Это позволяет нашим клиентам поддерживать бесперебойную работу установленного оборудования и осуществлять модернизацию по мере устаревания компонентов.

По мере развития отрасли конкуренция усиливается, новые компании больше не могут выходить на этот рынок, цены падают и устанавливаются барьеры выхода. Легко ли выйти на рынок 
Does the company produce such products as structured and gas filled core fibers?

Mr. Id: Rosendahl Nextrom is a producer of equipment which allows our customers to make optical fibers and cables and Nextrom has many customers which are currently making these types of fibers.

Wireless communication - Is this technology a threat to the FO industry?

Mr.Id: Not really, wireless is limited in distance and currently wireless transmitters and receivers are connected to the network with optical fibers. Due to environmental, physical, and EM interference, wireless communication cannot really meet the bandwidth requirements over long distances as optical fibers can.

How long does it take to develop a new product?

Mr. Id: It greatly depends on the product and the complexity. Some can be very difficult and take 5-10 years in order to develop a new product and release it into the commercial market.

What is the product life time - for example, for the Draw Tower?

Mr.Id: Many of the Nextrom draw towers are still in production after $20+$ years. Nextrom continually supports our customers with our service department to ensure that our customers can keep their machines working and can keep the equipment up to date as components become obsolete.

As the industry develops, the competition increases, new firms can no longer enter this market, prices are falling down and standards are being set. Is it easy to enter the optical fiber market? Who has set the barriers?

Mr. Id: Again there is a disparity between entering the telecom or specialty fiber market. The current telecom market is very competitive requiring a new firm to make a large investment to capitalize on the economics of scale while at the same time they must be very efficient with high output and yields. The specialty market is still quite diverse so there are still many different areas where newcomers can find their niche. But as the market develops more and more, these will also become more difficult.

\section{Fiber supply capacity now exceeds global demand, but preform capacity not all available for every draw plant...}

What distinguishes the company's products from competitors' products, what are the advantages?

Mr.Id: Nextrom is the largest supplier of optical fiber production equipment and we are the only supplier to supply the entire product range from preform manufacturing, to fiber draw, post draw, and cabling. This allows us to be a turnkey supplier. In addition our size allows for local service and support in many places around the world. Nextrom equipment is known for quality and reliability and allow our customers to perform R\&D or full scale production with long term reliability and support.

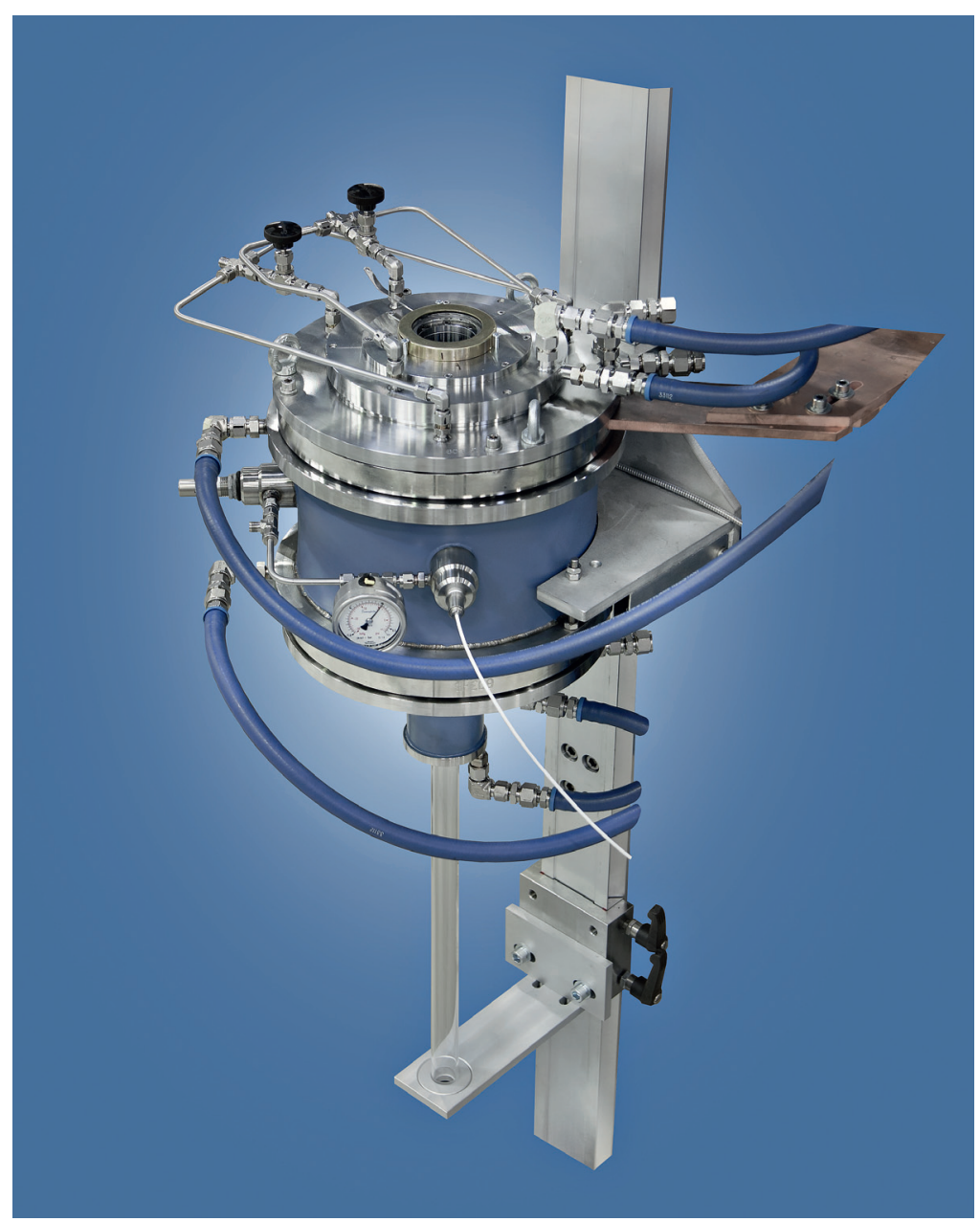


оптических волокон? Кто устанавливает барьеры?

Т.и.: Существует несоответствие между выходом на рынки телекоммуникационного или специализированного оптического волокна. Современный телекоммуникационный рынок явля-

\section{По мере того, как рынок будет развиваться, барьеры выхода будум более ощутимыми...}

ется очень конкурентным, требующим от новой компании больших инвестиций в технологию и производствен ${ }^{-}$ ные мощности. Специализированный

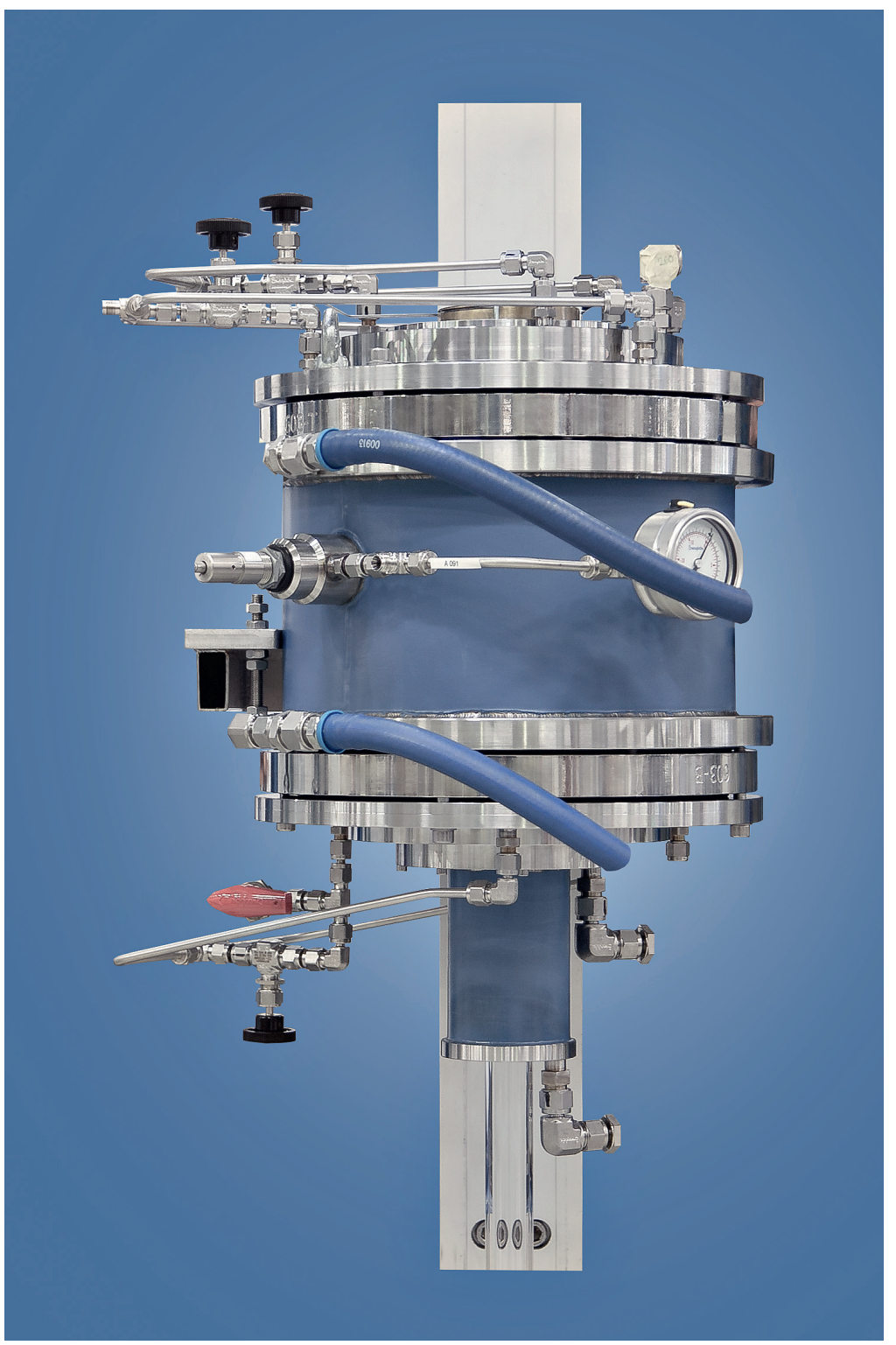

оптико-волоконный рынок по-прежнему довольно разнообразен, поэтому новички могут найти свою нишу. По мере того, как рынок будет развиваться, барьеры выхода будут более ощутимыми.

Что отличает продукцию компании от продукции конкурентов, каковы преимущества?

Т.И.: Nextrom является крупнейшим поставщиком оборудования для производства оптических волокон, и мы являемся единственным поставщиком, который поставляет весь ассортимент продукции от производства преформ, башен вытяжки волокна и до оборудования для производства кабеля. Это позволяет нам осуществлять поставки оборудования на производство под ключ. Кроме того, наш опыт и размер компании позволяют оказывать поддержку нашим клиентам по всему миру. оборудование Nextrom славится качеством и надежностью и позволяет нашим клиентам выполнять НИОКР или полномасштабное производство на долгосрочной основе и при постоянной поддержке.

К.Б.: Мы расширяем и совершенствуем наш научно-исследовательский центр. Планируется, что обновленный центр начнет свою работу в 2019 году. Наличие своего собственного оборудования для испытаний и совершенствования технологического процесса является огромным преимуществом для нас и наших заказчиков. Наша компетентность позволяет обеспечивать удаленную поддержку производителя, используя его параметры производства на нашем оборудовании, что отвечает потребностям всех участвующих сторон, особенно в период ввода в эксплуатацию оборудования на предприятии заказчика.

Как изменились потребности клиентов за последние десять лет?

Т.И.: По мере увеличения объемов рынка клиенты сосредоточили свое внимание на сокращении эксплуатационных расходов и повышении производительности. Это означает использование в производстве преформ с большим диаметром, например. Однако процесс 
Mr. Boll: We are expanding and improving our research center. It is planned that the renovated center will start its work in 2019. Having our own equipment to test and improve the process is a huge advantage for us and our customers. Our expertise allows us to provide remote support to the customer using its production parameters on our equipment, which meets the needs of all parties involved, especially during the commissioning of the equipment at the Customer's site.

How have the customer needs changed over the past ten years?

Mr.Id: As market volumes have increased, customers have focused on reducing operating costs and increasing yield. This means larger scale preform production, faster drawing speeds with larger preforms, and more automation and online product verification.

How often do the same customers buy the company's products?

Mr.Id: At Nextrom we put a strong focus on long term customer relationships. This means that we have many repeat customers, some of which have been buying Nextrom equipment exclusively for over 20 years.

Does the development of the medical field (for example, brain mapping) change your equipment?

Mr.Id: Our specialty fiber products are used to make many types of optical fiber sensors. Nextrom works with our customers to customize their production equipment to meet their specific optical fiber needs.

Mr. Boll: Optical fiber production is influenced by the reduction of global natural gas reserves, such as helium and its increased use in industry. Helium is used in cooling systems to improve the transfer of heat from the surface of the optical fiber to the cooling system. The use of heliumbased cooling processes has been growing rapidly in recent years. This is reflected in the price of helium. In 2000, the price of premium helium was $\$ 2.80 / \mathrm{m}^{3}$ where its price in today's market is more than $\$ 20 / \mathrm{m}^{3}$. This rise in the cost of helium has an impact on the cost of fiber production, as helium consumption increases in line with production speed. There is no escaping the fact that growing helium prices induce growing costs for the fiber manufacturing market which can typically be in the range of $\$ 0.05$ to $\$ 0.10$ per kilometer of fiber.

\section{But as the market develops more and more, these will also become more difficult...}

Now, Nextrom has developed a system for fiber draw, where the helium gas released from the cooling system can be collected and cleaned for re-use in the very same fiber cooling system. Helium Recovery System has been welcomed with open arms since its launch and in a short period time acquired a strong foothold in the market with over 70 machines sold and it's considered now as an industry standard among the biggest fiber producers in the world.

The system can provide a recycled helium recovery rate in excess of $90 \%$ to even $97 \%$. These results indicate why it's been so popular among our customer's. Return on investment depends on nominal helium consumption and the price of helium, but for a typical tower with the line speed 1800 $\mathrm{m} / \mathrm{min}$, payback time of the recovery unit is approximately 1 year.

Incorporation of the two companies - what purposes was this strategic alliance made for? Are these goals achieved?

Mr.Id: The merger of Rosendahl and Nextrom allowed us to capitalize on each other's strengths as well as reduce product costs resulting in savings for our customers. In the overlapping equipment such as Optical Fiber Cable Production Machinery, customers are able to combine equipment from either company to created a tailored line to meet their needs. In other product areas we have leveraged our larger scale to achieve lower equipment and component pricing from our vendors which has resulted in reduced prices for our customers.

Editorial board specially thanks Rosendahl Nextrom Russian office for support in arranging the interview 
вытяжки таких преформ более трудоемкий и требует усовершенствований. Мы долго работали над этим и смогли представить решение, которое позволяет также сэкономить пространство и использовать его для увеличения скорости охлаждения волокна естественным путем, что позволило увеличить скорость вытяжки.

\section{На производство оптического волокна оказывает виияние сокращение мировых запасов природного газа...}

Как часто одни и те же клиенты покупают продукцию компании?

Т.и.: Компания Nextrom особый акцент ставит на установление долгосрочных отношений с клиентами. А это означает, что у нас много постоянных клиентов, некоторые из которых покупают оборудование исключительно у компании Nextrom уже более 20 лет.

Как развитие, например, медицинской сферы влияет на выпускаемое вами оборудование?

Т.И.: Наше оборудование для производства специализированного волокна используется, чтобы изготовить волокна различных видов. Nextrom работает со своими клиентами на индивидуальной основе, чтобы удовлетворить конкретные потребности в производстве оптического волокна наших клиентов.

К. Б.: На производство оптического волокна оказывает влияние сокращение мировых запасов природного газа, например гелия, и увеличение его использования в промышленности. Это отражается на цене гелия. В 2000 году цена премиального гелия составила $\$ 2,80 / \mathrm{M}^{3}$

Гелий используется в системах охлаждения. В последние годы процессы охлаждения на основе гелия быстро растут. Это отражается в цене гелия. В 2000 году цена премиум гелия составила $\$ 2,80 / \mathrm{m}^{3}$, в то время, как его цена на современном рынке составляет более $\$ 20 / \mathrm{M}^{3}$. Этот рост стоимости гелия влияет на стоимость производства волокон, так как потребление гелия увеличивается в соответствии с увеличением масштабов производства. Растущие цены на гелий вызывают растущие расходы на рынке производства волокон, которые, как правило, могут быть в диапазоне от \$0,05 до $\$ 0,10$ за километр волокна.

Nextrom разработала систему вытяжки волокна, где гелий газ, выделяемый из системы охлаждения может быть собран и очищен для повторного использования в той же системе охлаждения волокна - система рекуперации гелия.

Система рекуперации была хорошо встречена на рынке, более 70 машин продано нашим клиентам, и она рассматривается в настоящее время в качестве стандарта промышленности среди крупнейших производителей волокна.

Система может обеспечить степень рекуперации свыше 90\% и даже до 97\%. Эти цифры показывают, почему она так популярна среди наших клиентов.

Окупаемость инвестиций зависит от номинального потребления гелия и цены, но для типичной башни со скоростью линии 1800 м/мин окупаемость составляет около 1 года.

Объединение двух компаний, для каких целей был создан этот стратегический союз? Достигнуты ли эти цели?

т.И.: Слияние Rosendahl и Nextrom позволило нам извлечь выгоду из сильных сторон друг друга, а также снизить затраты на нашу продукцию, что привело к экономии для наших клиентов. Это также позволяет нашим клиентам, например, в такой сфере как производство оборудования для кабельных линий, комбинировать оборудование наших компаний, чтобы создать индивидуальную линию и полностью удовлетворить производственные потребности.

Редакция журнала ФоТОНИКА благодарит сотрудников российского отделения компании Rosendahl Nextrom за организацию интервью 
: (1)

\section{Главное событие отрасли в России и странах СНГ}

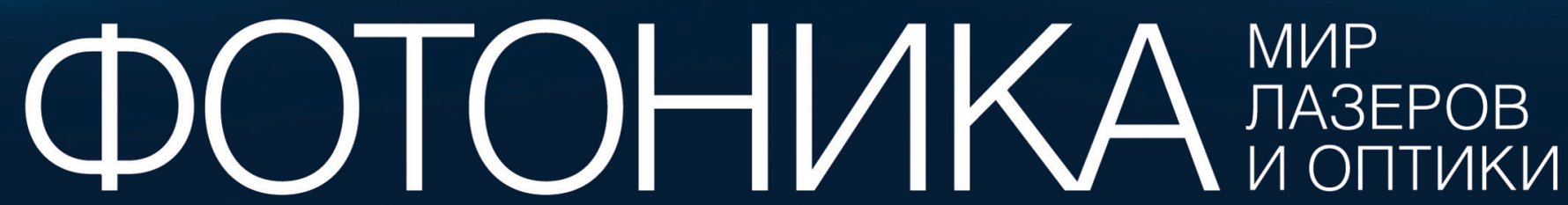

31 марта-3 апреля 2020

При поддержке Министерства

промышленности и торговли РФ

Под патронатом ТПП РФ

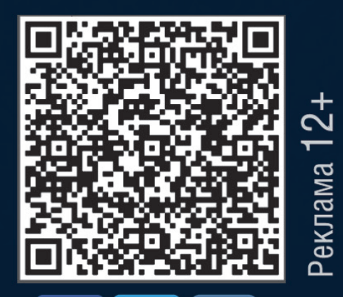

$f D P$ 15-я юбилейная международная специализированная выставка лазерной, оптической и оптоэлектронной техники

Россия, Москва, ЦВК «Экспоцентр» www.photonics-expo.ru 